\title{
Innovative Quality Improvement by Continuous Microwave Processing of a Faba Beans Pesto Sauce
}

\author{
Tâmmila Venzke Klug ${ }^{1} \cdot$ Elena Collado $^{2}$ • Ascensión Martínez-Sánchez ${ }^{1,2}$. \\ Perla A. Gómez ${ }^{2}$ Encarna Aguayo ${ }^{1,2}$ - Mariano Otón ${ }^{2}$. Francisco Artés ${ }^{1,2}$. \\ Francisco Artés-Hernandez ${ }^{1,2}$ (i)
}

Received: 10 July 2017 / Accepted: 6 November 2017 / Published online: 25 November 2017

(C) The Author(s) 2017. This article is an open access publication

\begin{abstract}
Nowadays, consumers demand healthy, safe, and ready-to-eat horticultural products because of their lifestyle. In this regard, new legume-based food product development with eco-innovative technologies seems to be an interesting market. The effect on quality of an innovative pesto sauce, made of fresh faba bean seeds, of an alternative continuous microwave treatment pasteurization (MW, $11 \mathrm{~kW} ; 30 \mathrm{~s}) \mathrm{re}-$ garding a conventional pasteurization $\left(85^{\circ} \mathrm{C} ; 5 \mathrm{~min}\right)$ throughout 20 days at $5{ }^{\circ} \mathrm{C}$ was studied. Non-heated blended samples were used as control. The microbial quality was satisfactory in all treatments. MW treatment improved the sensorial quality of pesto sauce and decreased condensed tannins. Additionally, MW-treated samples showed the best texture, consistency, and color, preserving its chlorophyll and carotenoid content. On the other hand, thermal treatments showed a decrease in total phenolic compounds (TPC) and antioxidant capacity (TEAC) after heating, regarding control samples; however, TPC and TEAC remained quite constant throughout the storage.
\end{abstract}

Keywords Vicia faba L. · Ready-to-eat · Minimal processing $\cdot$ Alternative pasteurization $\cdot$ Mild thermal processing

Francisco Artés-Hernandez

fr.artes-hdez@upct.es

1 Postharvest and Refrigeration Group, Department of Food Engineering, Universidad Politécnica de Cartagena (UPCT), Paseo Alfonso XIII, 48. 30203, Cartagena, Murcia, Spain

2 Institute of Plant Biotechnology (IBV), UPCT, Campus Muralla del Mar s/n. 30202, Cartagena, Murcia, Spain

\section{Introduction}

There is an actual trend towards increasing the consumption of healthy foods due to that consumers are really concerned about the influence of diet on health and well-being. Therefore, the food industry needs to produce healthy innovative ready-to-eat high-quality and safe products to satisfy the demand of consumers. Previous studies have described a positive association between plant-based diets with increased intake of legumes and health (Lima et al. 2016). Particularly, the development of new legume-based elaborates, like faba beans, could be an interesting market, i.e., faba bean seeds contain $22.4-36 \%$ protein, $57.8-61 \%$ carbohydrates, $12 \%$ fiber, and $1.2-4 \%$ lipids (Hedley 2001). In addition, faba beans can be recommended as a good folate source, as a $100-\mathrm{g}$ portion of green faba bean seeds provides $120 \mu \mathrm{g}$ of dietary folate equivalents (Hefni et al. 2015). Furthermore, an important phenolic content and antioxidant activity of faba beans have been previously reported (Baginsky et al. 2013). Moreover, a therapeutic potential to treat Parkinson's disease has been described since faba beans provide L-3,4-dihydroxyphenylalanine (LDOPA), the precursor to the neurotransmitter catecholamine (Randhir and Shetty 2004). Therefore, previous studies showed faba beans as an interesting food to develop innovative food products due to its beneficial health implications.

Processing technologies which can guarantee safety and stability while offering high-quality products may be the key to prolonging the shelf-life and satisfying the current consumer demand (Picouet et al. 2009). Microwave (MW) pasteurization is a thermal technology considered as an interesting alternative to conventional techniques. MW heating has a number of quantitative and qualitative advantages over conventional heating techniques (Marszalek et al. 2015; Bornhorst et al. 2017). The main advantage is that heat is generated inside the product itself. Therefore, it can be heated 
in a shorter time and even with more temperature diffusion. Such advantages often increased yield and production rate and/or led to an improved product quality.

Previous studies have evaluated the microbial and sensory quality, as well as the nutrient content and bioactive compounds associated to MW cooking. Arjmandi et al. (2017) showed that MW treatment with high power/short time $(1900 \mathrm{~W} / 180 \mathrm{~s}, 2700 \mathrm{~W} / 160 \mathrm{~s}$, and $3150 \mathrm{~W} / 150 \mathrm{~s})$ in tomato puree improved the viscosity as well as lycopene extraction and better decreased the enzyme residual activity (PG and PME) than conventional heating. Benlloch-Tinoco et al. (2015) studied the impact of MW (1000 W/340 s) and conventional pasteurization on the shelf life of a kiwifruit puree and observed a higher preservation of bioactive compounds (57-67\%) in MW-treated samples regarding conventional pasteurization. In addition, Arjmandi et al. (2016) reported a better color retention of an orange-colored smoothie after an alternative pasteurization treatment provided by MW at $90 \pm$ $2{ }^{\circ} \mathrm{C}$ for $35 \mathrm{~s}$. Similar results were reported by Guzmán et al. (2002), who observed a greener color in avocado puree treated with MW power density for a shorter time $(31.65 \mathrm{~W} / \mathrm{g}, 30 \mathrm{~s})$.

The aim of the present study was to develop an innovative pesto sauce, made of fresh faba bean seeds, and evaluate the effect of an alternative MW processing treatment on the microbial, sensory, and nutritional quality changes, as well as on the bioactive compound content during the storage for 20 days at $5{ }^{\circ} \mathrm{C}$ in darkness.

\section{Materials and Methods}

\section{Pesto Sauce from Faba Beans}

A new pesto sauce ( $73 \%$ fresh faba beans (Vicia faba L. var. minor cv. Palenca), $22 \%$ olive oil, $3.63 \%$ lemon juice, $0.55 \%$ vinegar, $0.4 \%$ salt, $0.4 \%$ sugar, $0.02 \%$ garlic powder; $\mathrm{pH}=$ $5.0)$ was previously optimized based on sensory quality evaluations of a previously discriminatively trained panel $(n=11)$ from the UPCT. All ingredients were purchased at a local supermarket from Cartagena (Murcia, Spain).

\section{Treatments and Storage Conditions}

All ingredients were blended in a Robot Cook ${ }^{\circledR}$ (Robot Coupe, Montceau-en-Bourgogne, France) for $30 \mathrm{~s}$ at $1.450 \times g$ (control treatment, CTRL). Then, pesto sauce samples (approximately $1 \mathrm{~kg}$ ) were heated in the same blender for conventional pasteurization $(\mathrm{CP})$ at $85 \pm 2{ }^{\circ} \mathrm{C}$ during $5 \mathrm{~min}$ while samples (approximately $1 \mathrm{~kg}$ ) for microwave treatment (MW) were packed in polyethylene bags embossed (100 g) and treated for $30 \mathrm{~s} / 11 \mathrm{~kW}$ in an innovative semi-industrial prototype of a continuous microwave oven (SI-MAQ0101, Sairem Ibérica SL, Barcelona, Spain) which was previously described (Arjmandi et al. 2016; Castillejo et al. 2017). Briefly, the microwave oven consisted of four adjustable magnetrons $(0.5-3.0 \mathrm{~kW} ; 2450 \mathrm{MHz})$, a polytetrafluoroethylene (PTFE) feed belt able to work on continuous or back-andforth movement mode (semi-continuous), an optimized heating chamber, new energy economizing filters, a computer interface, and a fiber optic slip ring for online temperature measurements inside the microwave oven. MW consisted of a semi-continuous mode with back-and-forth movement of $2 \mathrm{~m} \mathrm{~min}^{-1}$ belt speed at $11 \mathrm{~kW}(3+3+3+2 \mathrm{~kW})$ for $30 \mathrm{~s}$. MW treatment was previously optimized in order to achieve a fast heating of $85^{\circ} \mathrm{C}$, checked with a portable fiber optic thermometer (Neoptix NOMAD Fiber NMD, Neoptix, Quebec, Canada). The reflected power from each magnetron was $360 \mathrm{~W}$ resulting in a final MW power of $9.56 \mathrm{~kW}(2.64+$ $2.64+2.64+1.64 \mathrm{~kW})$. After the MW treatment, samples reached a temperature of $85 \pm 5{ }^{\circ} \mathrm{C}$. As control samples (CTRL), non-heated blended samples were used. Immediately after processing (CTRL, CP, and MW), samples of $100 \mathrm{~g}$ were vacuum sealed (Egarvac, Barcelona, Spain) and cooled up to $5^{\circ} \mathrm{C}$ in an ice-water bath. Packages were stored at $5{ }^{\circ} \mathrm{C}$ in darkness. Three packages from each sample batch (CTRL, CP, and MW) of faba bean pesto sauce were immediately evaluated after processing (day 0 ) and after 5, 8, 14, and 20 days of storage for physicochemical, sensory, and microbial analyses. The remaining quality analyses were carried out in frozen samples at $-80^{\circ} \mathrm{C}$.

\section{Physicochemical Analyses}

Samples were used to determine the $\mathrm{pH}$ by a $\mathrm{pH}$ meter (Crison 2001 pH meter, Crison Instruments SA, Barcelona, Spain). Titratable acidity (TA) was determined by the titration of $5 \mathrm{~g}$ of samples $+45 \mathrm{~mL}$ of distilled water with $0.1 \mathrm{~mol} \mathrm{~L}^{-1} \mathrm{NaOH}$ to $\mathrm{pH} 8.1$ (T50, Mettler Toledo, Milan, Italy) and expressed as grams of malic acid per $100 \mathrm{~mL}$. Color was determined using a colorimeter (Minolta CR-300 Series, Japan), and the results were expressed as CIE L*a*b* color space units. Total color differences $(\Delta \mathrm{E})$ throughout storage were compared to their respective initial values according to equations previously described by Walkling-Ribeiro et al. (2010). $\Delta \mathrm{E}$ were expressed as

$E={ }^{1 / 2}\left(\left\lfloor\left(L_{0}-L^{*}\right)^{2}+\left(a_{0}-a^{*}\right)^{2}+\left(b_{0}-b^{*}\right)^{2}\right\rfloor\right)$

\section{Total Carotenoid and Chlorophyll Content}

The sample preparation for chlorophyll determination was conducted as previously reported Rodríguez-Hidalgo et al. (2010), with light modifications, wherein the total chlorophyll pigments were extracted with hexane. Briefly, frozen samples $(0.5 \mathrm{~g})$ were mixed with hexane $(9 \mathrm{~mL})$ and $15 \mathrm{~mL}$ of a 
mixture of methanol-acetone $(1: 2, v / v)$. The extraction was carried out by using an orbital shaker (Stuart, Staffordshire, UK) at $200 \times g$ at $4{ }^{\circ} \mathrm{C}$ for $4 \mathrm{~h}$ in darkness. After extraction, $25 \mathrm{~mL}$ of $1 \mathrm{M} \mathrm{NaCl}$ was added and samples were vortex mixed. The upper layer was used to determine the chlorophyll and carotenoid contents. The absorbance (A) at 662, 644, and $470 \mathrm{~nm}$ was measured using a UV-visible spectrophotometer (Hewlett Packard, model 8453, Columbia, USA) in sample extracts $(1 \mathrm{~mL})$. The equations developed by Wellburn (1994) were used to determine the individual content of chlorophyll a $(\mathrm{Ca}=10.05 \times \mathrm{A} 662-0.766 \times \mathrm{A} 644)$, chlorophyll b $(\mathrm{Cb}=16.37 \times \mathrm{A} 644-3.14 \times \mathrm{A} 662)$, total chlorophylls $(\mathrm{Ca}+$ $\mathrm{Cb})$, and total carotenoids $[\mathrm{Cx}+\mathrm{c}=(1000 \times \mathrm{A} 470-1.28 \times$ $\mathrm{Ca}-56.7 \times \mathrm{Cb}) / 205]$. Chlorophyll and total carotenoid contents were expressed as milligrams per kilogram of fresh weight (fw). All measurements were made in triplicate.

\section{Sugar and Organic Acid Contents}

The sucrose content and organic acids (citric and malic) were calculated according to Flores et al. (2012) with some modifications. Frozen pesto sauce samples ( $3 \mathrm{~g})$ were homogenized (Ultra-Turrax T-25, Ika-Labortechnik, Staufen, Germany) with cold water $(10 \mathrm{~mL})$ for $1 \mathrm{~min}$. The extracts were filtrated with a cheesecloth and centrifuged at $12,000 \times \mathrm{g}$ for $20 \mathrm{~min}$ at $4{ }^{\circ} \mathrm{C}$. The supernatant was purified by passing through a column of solid phase extraction in a parallel Strata C18-E column (55 $\mu \mathrm{m}, 70$ A; Phenomenex, Macclesfield, UK), and samples were filtered through a 0.45 - $\mu \mathrm{m}$ PTFE syringe filter. Chromatographic analyses were carried out on an ultra-highperformance liquid chromatography instrument (UHPLC) (Shimadzu, Kyoto, Japan) equipped with a DGU-20A degasser, LC-30AD quaternary pump, SIL-30AC autosampler, CTO-10AS column heater, and SPDM-20A photodiode array detector. The UHPLC system was controlled by the software LabSolutions (Shimadzu, v5.42 SP5). Chromatographic analyses were carried out onto a RAMCarbohydrate Ag+ (Phenomenex, Macclesfield, UK) column. The column temperature was maintained at $25^{\circ} \mathrm{C}$. Sulfuric acid $0.001 \mathrm{~N}$ as the mobile phase was used with an isocratic flow rate of $1.0 \mathrm{~mL} \mathrm{~min}^{-1}$, and the injection volume $20 \mu \mathrm{L}$. Quantification and assignment of peaks were based on the peak areas and retention times of known standard curves for purified sucrose, acid citric, and acid malic (Sigma, St. Louis, MO, USA). The results were expressed as milligrams per kilogram of fw.

\section{Determination of Condensed Tannins}

Frozen samples ( $3 \mathrm{~g}$ ) were homogenized (Ultra-Turrax T-25, Ika-Labortechnik, Staufen, Germany) with methanol (6 mL) for $1 \mathrm{~min}$, and the extraction was carried out in an orbital shaker (Stuart, Staffordshire, UK) for $20 \mathrm{~min}$ at $200 \times \mathrm{g}$. The extracts were centrifuged at $15,000 \times \mathrm{g}$ for $10 \mathrm{~min}$ at $4{ }^{\circ} \mathrm{C}$.

The condensed tannins were colorimetrically assayed by the method of vanillin- $\mathrm{HCl}$ according to Price et al. (1978). One milliliter of supernatant, $2.5 \mathrm{~mL}$ of $1 \%$ vanillin reagent, and $2.5 \mathrm{~mL}$ of solution $\mathrm{HCl} 8 \%$ were added and incubated for $20 \mathrm{~min}$ in a water bath at $30{ }^{\circ} \mathrm{C}$ under continuous agitation. The sample absorbance was read at $500 \mathrm{~nm}$. Methanol was used as a blank, and catechin (+; Sigma Chemical Co., St Louis, MO) was used as standard to made the calibration curves. The condensed tannin content was expressed as milligrams of catechin equivalents (CE) per kilogram of fw.

\section{Total Phenolic Content}

Frozen pesto sauce samples $(0.5 \mathrm{~g})$ were placed in glass bottles and homogenized (Ultra-Turrax T-25, Ika-Labortechnik, Staufen, Germany) with methanol $(3 \mathrm{~mL})$ for $1 \mathrm{~min}$. The extracts were centrifuged at $15,000 \times g$ for $10 \mathrm{~min}$ at $4{ }^{\circ} \mathrm{C}$. The supernatant was used to determine the total phenolic content (TPC) by the Singleton and Rossi (1965) method, but with some modifications (Martínez-Hernández et al. 2011). Supernatant samples $(19 \mu \mathrm{L})$ and $29 \mu \mathrm{L}$ of $1 \mathrm{~N}$ FolinCiocalteu reagent were mixed in a well plate and incubated for $3 \mathrm{~min}$ at room temperature in dark conditions. Then, $192 \mu \mathrm{L}$ of a solution containing $\mathrm{Na}_{2} \mathrm{CO}_{3}(0.4 \%)$ and $\mathrm{NaOH}$ ( $2 \%$ ) was added. After $45 \mathrm{~min}$ of incubation at room temperature in dark conditions, the absorbance was measured at $750 \mathrm{~nm}$ and TPC was expressed as milligrams of gallic acid equivalents (GAE) per kilogram of fw.

\section{Total Antioxidant Capacity}

The same sample extracts to determine TPC were used to evaluate the antioxidant capacity (TEAC) by 2,2-diphenyl-1picrylhydrazil (DPPH) (Brand-Williams et al. 1995) and ferric reducing antioxidant power (FRAP) (Benzie and Strain 1999) assays.

DPPH Assay The free radical scavenging activity using the free radical DPPH was evaluated by measuring the decrease in absorbance at $515 \mathrm{~nm}$ for $30 \mathrm{~min}$. A volume $(194 \mu \mathrm{L})$ of DPPH solution $(0.7 \mathrm{mM})$ was added to each extract sample $(21 \mu \mathrm{L})$.

FRAP assay The freshly made-up FRAP solution containing sodium acetate buffer ( $\mathrm{pH}$ 3.6), 10 mM TPTZ solution (in $40 \mathrm{mM} \mathrm{HCl}$ ), and $20 \mathrm{mM} \mathrm{FeCl} 3$ was prepared in a $v / v / v$ proportion of 10:1:1. A volume $(198 \mu \mathrm{L})$ of FRAP solution was reacted to each extract sample $(6 \mu \mathrm{L})$ for $45 \mathrm{~min}$ at room temperature in darkness, and an increase in absorbance was determined at $593 \mathrm{~nm}$. 
The antioxidant activity for DPPH and FRAP assays was expressed as Trolox equivalent antioxidant capacity (TEAC) per kilogram of fw.

\section{Sensory Analyses}

Sensory analyses were performed according to international standards (ASTM 1986). Tests were conducted in a standard room (ISO 2007) equipped with ten individual taste boxes using the white light. Samples (about $20 \mathrm{~g}$ ) were served at room temperature in transparent glasses coded with three random digit numbers. Still mineral water was used as palate cleanser. The sensory evaluation of the faba bean pesto sauce was carried out by 11 members (aged 22-69 years) previously trained in discriminative quality attributes and the ability to communicate sensory descriptions of products according to Klug et al. (2017). The panel was screened for sensory ability (color, flavor, texture, taste, consistency, overall quality) on a 5-point structured hedonic scale (5: excellent, 4: good, 3: limit of acceptability, 2: poor, 1: extremely bad).

\section{Microbial Analyses}

To determine the mesophilic, psychrophilic, Enterobacteriaceae, yeast and mold growth, standard enumeration methods were used according to Castillejo et al. (2016). The following media and incubation conditions were used: plate count modified agar (PCA) (Scharlau Chemie, Barcelona, Spain) for mesophilic and psychrotrophic aerobic bacteria, incubated at $37^{\circ} \mathrm{C}$ for $48 \mathrm{~h}$ and at $5^{\circ} \mathrm{C}$ for 7 days, respectively; Violet Red Bile Dextrose agar (Scharlau Chemie, Barcelona, Spain) for enterobacteria, incubated at $37{ }^{\circ} \mathrm{C}$ for $48 \mathrm{~h}$; and Rose Bengal agar (Scharlau Chemie, Barcelona, Spain) for yeasts and molds, incubated for 3-5 days at $25{ }^{\circ} \mathrm{C}$. The presence of Salmonella spp., Listeria monocytogenes, and generic Escherichia coli was monitored according to the European legislation (Regulation EC 1441/ 2007 2007). All microbial counts were reported as log colony forming units per gram of product $\left(\log \mathrm{CFU} \mathrm{g}{ }^{-1}\right)$. Each of the three replicates was analyzed by duplicate.

\section{Statistical Analysis}

An analysis of variance (ANOVA) was performed for comparing different treatments and storage times at a significant level of $P \leq 0.05$ using PASW Statistics 22 for Windows (SPSS Inc., Chicago, IL, USA). In some cases, when significant differences were observed, Tukey's HSD (Honestly Significant Difference) test was applied. Bilateral correlations were determined by Pearson's correlation coefficient with a confidence interval established at $95 \%$.

\section{Results and Discussion}

\section{Effect of Thermal Treatments on Physicochemical Quality Attributes}

Faba bean pesto sauce showed a $\mathrm{pH}$ decrease just after heat treatments and a subsequent light $\mathrm{pH}$ decrease and TA increase after 14 days at $5{ }^{\circ} \mathrm{C}$ (Table 1). MW samples showed the lowest $\mathrm{pH}$ decrease (around 0.03 units) and the lowest increase in TA (around 0.14 units).

On the other hand, color of the pesto sauce was affected by treatments. After thermal treatments, a lightness ( $\mathrm{L}^{*}$ ) decrease was observed regarding CTRL samples (Fig. 1b), without differences between MW and CP treatments. This trend was maintained during storage.

However, at the end of storage, an increase in $\mathrm{L}^{*}$ was observed in all samples (CTRL, CP, and MW) (Fig. 1b). The chromatic $\mathrm{a}^{*}$ and $\mathrm{b} *$ index showed a different behavior among treatments and also throughout storage. Thermal treatments increased $\mathrm{a}^{*}$ values, with the highest value detected in $\mathrm{CP}$ samples, while MW treatment showed the highest $b^{*}$ value. As a result, processed samples slightly changed to less yellow tones. The color of faba bean pesto sauce after microwave treatment changed from light green to dark green $\left(a^{*}\right.$ and $b^{*}$ increasing). MW treatment preserved the pigments improving the appearance to that obtained with CP treatment. The increase of chromatic $\mathrm{a}^{*}$ index and decrease of $\mathrm{b}^{*}$ have been previously reported by Benlloch-Tinoco et al. (2014), where a more luminous kiwifruit puree was obtained under MW treatment $(1000 \mathrm{~W} / 340 \mathrm{~s})$, due to the preservation of pigments instead of the typical browning reactions in heating processes. Throughout storage, a* chromatic index increased after 5 days at $5{ }^{\circ} \mathrm{C}$ (Fig. 1a), while a decrease in $\mathrm{b}^{*}$ index was observed after 8 days at $5^{\circ} \mathrm{C}$ (data not shown). All treatments showed relevant color differences $(\Delta \mathrm{E})$ from day 8 , and this trend was maintained until the end of storage (Fig. 1c). According to our results, Marszalek et al. (2015) found minor color changes in strawberry puree after two continuous MW treatments $(90 \pm$ $1{ }^{\circ} \mathrm{C}$, at atmospheric pressure or at $120 \pm 1{ }^{\circ} \mathrm{C}$ and $0.35 \mathrm{MPa}$ with a holding time of $10 \mathrm{~s}$ ). De Ancos et al. (1999) also reported that MW heating induced slight color changes in strawberry puree. A high significant $(p<0.01)$ negative correlation was observed between $\mathrm{a} *$ index and $\mathrm{pH}(-0.597)$ and between $\mathrm{a}^{*}$ index and TA $(-0.742)$.

\section{Effect of Thermal Treatments on Total Carotenoids and Chlorophylls}

The initial total chlorophyll content of CTRL samples was $31.6 \pm 5.7 \mathrm{mg} \mathrm{kg}^{-1} \mathrm{fw}$ (Table 2). Chlorophyll a represents around $77 \%$ of total chlorophyll content of pesto sauce of faba beans. Petzold et al. (2014) showed that broad bean seeds (Vicia faba L) var. major cv. Aguadulce contained 19.4 
Table $1 \mathrm{pH}$ and titratable acidity (TA) changes during storage at $5^{\circ} \mathrm{C}$ of untreated control (CTRL), conventional pasteurization $(\mathrm{CP})$, and microwave (MW) treated faba bean pesto sauce

\begin{tabular}{|c|c|c|c|}
\hline Day & Treatment & $\mathrm{pH}$ & $\mathrm{TA}\left(\mathrm{g}\right.$ malic acid $\left.100 \mathrm{~mL}^{-1}\right)$ \\
\hline \multirow[t]{3}{*}{0} & CTRL & $4.90 \pm 0.01 \mathrm{Aa}$ & $0.41 \pm 0.01 \mathrm{NSc}$ \\
\hline & $\mathrm{CP}$ & $4.83 \pm 0.06 \mathrm{Ca}$ & $0.41 \pm 0.03 \mathrm{NSb}$ \\
\hline & MW & $4.83 \pm 0.06 \mathrm{Ba}$ & $0.44 \pm 0.02 \mathrm{NSb}$ \\
\hline \multirow[t]{3}{*}{5} & CTRL & $4.86 \pm 0.06 \mathrm{Aab}$ & $0.41 \pm 0.01 \mathrm{NSc}$ \\
\hline & $\mathrm{CP}$ & $4.80 \pm 0.01 \mathrm{Cab}$ & $0.49 \pm 0.03 \mathrm{NSb}$ \\
\hline & MW & $4.80 \pm 0.01 \mathrm{Bab}$ & $0.47 \pm 0.02 \mathrm{NSb}$ \\
\hline \multirow[t]{3}{*}{8} & CTRL & $4.90 \pm 0.01 \mathrm{Aa}$ & $0.43 \pm 0.01 \mathrm{NSc}$ \\
\hline & $\mathrm{CP}$ & $4.83 \pm 0.06 \mathrm{Ca}$ & $0.52 \pm 0.09 \mathrm{NSab}$ \\
\hline & MW & $4.87 \pm 0.06 \mathrm{Ba}$ & $0.46 \pm 0.01 \mathrm{NSb}$ \\
\hline \multirow[t]{3}{*}{14} & CTRL & $4.87 \pm 0.06 \mathrm{Ab}$ & $0.58 \pm 0.02 \mathrm{NSa}$ \\
\hline & $\mathrm{CP}$ & $4.70 \pm 0.01 \mathrm{Cb}$ & $0.55 \pm 0.05 \mathrm{NSab}$ \\
\hline & MW & $4.80 \pm 0.01 \mathrm{Bb}$ & $0.58 \pm 0.04 \mathrm{NSa}$ \\
\hline \multirow[t]{3}{*}{20} & CTRL & $4.87 \pm 0.06 \mathrm{Ab}$ & $0.52 \pm 0.06 \mathrm{NSb}$ \\
\hline & $\mathrm{CP}$ & $4.70 \pm 0.01 \mathrm{Cb}$ & $0.68 \pm 0.15 \mathrm{NSb}$ \\
\hline & MW & $4.77 \pm 0.06 \mathrm{Bb}$ & $0.65 \pm 0.04 \mathrm{NSa}$ \\
\hline Treatment & $* * *$ & & $* *$ \\
\hline Days & $* * *$ & & $* * *$ \\
\hline Days $\times$ treatment & NS & & $*$ \\
\hline
\end{tabular}

Values correspond to average value $(n=3) \pm \mathrm{SD}$. Different capital letters within the same column show significant differences between treatments. Different lowercase letters within the same column show significant differences between storage times

$N S$ not significant

${ }^{*} p<0.05 ; * * p<0.01 ; * * * p<0.001$
$0.9 \mathrm{mg} \mathrm{kg}^{-1}$ of total chlorophylls and that $68.5 \%$ was reported to be chlorophyll a. After treatments, total chlorophyll content was significantly $(p<0.01)$ lower in CP samples than in MW samples, without significant differences between CTRL and MW treatments (Table 2). Significant differences in total chlorophyll content were due to changes in chlorophyll a, in accordance with Zhao et al. (2013). Chlorophyll b was maintained after pasteurization treatments and during the storage (data not shown). Chlorophylls can be degradated under low $\mathrm{pH}$ conditions (Cano 1991) and by thermal processing. According to the literature, losses of chlorophylls brought about by thermal processing vary from 12 to $66 \%$ depending on the species, the usable part of the plant, and the treatment time/temperature binomial (Lisiewska et al. 2004; Murcia et al. 2000). At the end of storage, CP samples showed losses around $12 \%$ in the total chlorophyll content, while MW samples showed an increase around 14\% (Table 2).

On the other hand, MW-treated samples showed a higher total carotenoid content than CP samples, while carotenoid content in pasteurized samples (MW and CP) did not show significant differences regarding CTRL samples (Table 2). Total carotenoid content after MW treatment $(8.9 \pm$ $0.7 \mathrm{mg} \mathrm{kg}^{-1} \mathrm{fw}$ ) remained quite constant throughout the storage and showed highest values regarding CP samples ( $8.0 \pm$ $2.3 \mathrm{mg} \mathrm{kg}^{-1} \mathrm{fw}$ ). Arjmandi et al. (2017) showed that the 훽carotene content of tomato puree was also affected by heating method, and increased after continuous MW pasteurization regarding unheated CTRL samples by breaking down the cellulose structure of the plant cell walls (Van het Hof et al. 2000). At the end of storage, CP samples showed around $13 \%$ losses while MW samples reported around $8 \%$ losses (Table 2).

A significant $(p<0.01)$ negative correlation was observed between $\Delta \mathrm{E}$ and the pigments determined in the faba bean pesto sauce, reporting -0.447 with total chlorophyll content and -0.436 with total carotenoid content. The higher $\Delta \mathrm{E}$ value observed in CP treatment regarding MW treatment could be attributed to the highest $\mathrm{a}^{*}$ index, and mostly to the highest decrease in chlorophyll and carotenoid contents.

\section{Effect of Thermal Treatments on Sugar and Organic Acids}

After treatments, no significant differences were observed between samples in the citric acid content (Fig. 2b). After 5 days of storage at $5{ }^{\circ} \mathrm{C}$, a significant decrease $(p<0.001)$ was observed in the citric acid content from all samples, although the highest decrease was observed in CTRL samples (27\%) and the lowest decrease in MW samples (17\%) (Fig. 2b). After this, citric acid content was maintained until the end of storage in all samples. On the contrary, malic acid was unaffected by 


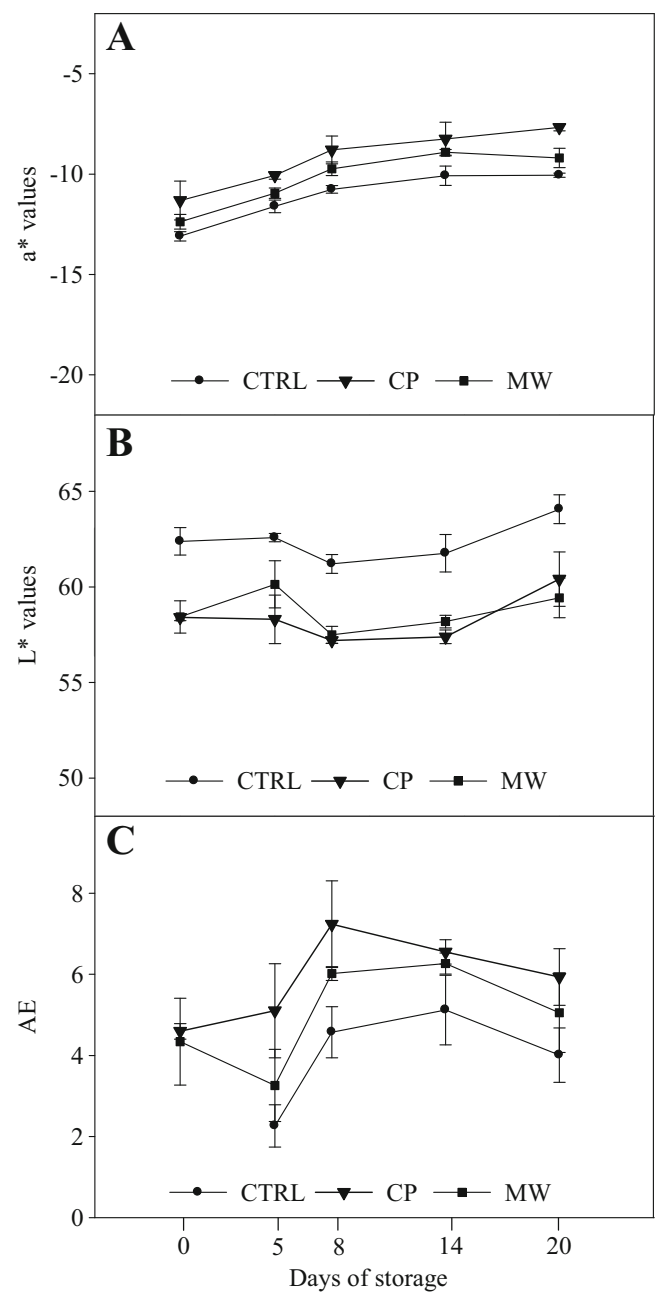

Fig. $1 \mathrm{a}^{*}(\mathbf{a}), \mathrm{L}^{*}(\mathbf{b})$, and $\Delta \mathrm{E}(\mathbf{c})$ color value changes during storage at $5{ }^{\circ} \mathrm{C}$ of untreated control (CTRL), conventional pasteurization (CP), and microwave (MW)-treated faba bean pesto sauce

treatments and was quite stable throughout the storage time (Fig. 2c).

The sucrose content of faba bean pesto sauce was lower than previous data reported in raw faba beans, and this could be due to different preharvest factors. Vidal-Valverde et al. (1998) evaluated the sucrose content in faba beans seeds (Vicia faba, L. major), which described values of $38.3 \pm$ $1.2 \mathrm{~g} \mathrm{~kg}^{-1}$ of dry matter $(\mathrm{dm})$. Few data have been published reporting the effects of processing on the soluble sugars of faba beans. In our study, sucrose content increased after CP (63.4\%) and MW (77.2\%) treatments regarding CTRL samples (Fig. 2a). According to our results, Shimelis and Rakshit (2005) evaluated sucrose content in common bean after MW treatment until $10 \mathrm{~min}$ and showed that the sucrose content was increased in the MW-heated samples. On the contrary, Vidal-Valverde et al. (1998) showed that the content of sucrose of faba bean seeds after citric acid soaking plus cooking $\left(100{ }^{\circ} \mathrm{C}, 35 \mathrm{~min}\right)$ was reduced by $72 \%$. After 5 days at $5{ }^{\circ} \mathrm{C}$, a decrease was observed in all samples, wherein CTRL samples showed the highest decrease with losses around $72 \%$, while CP samples and MW samples showed losses around 27 and $39 \%$, respectively. MW and CP samples showed lower sucrose content than CTRL ones after 20 days at $5{ }^{\circ} \mathrm{C}$ (Fig. 2a). According to Rao and Belavady (1978), a part of oligosaccharides could be present in bound form to proteins or to other macromolecules and thermal treatments may affect these bonds releasing the oligosaccharides.

\section{Effect of Thermal Treatments on Condensed Tannins, Total Phenolics Content, and Total Antioxidant Capacity}

Condensed tannin content of untreated CTRL pesto sauce was $5942 \pm 390 \mathrm{mg} \mathrm{CE} \mathrm{kg}^{-1}$ fw. Almeida et al. (2008) described a range for condensed tannins from 1.95 to $2.87 \mathrm{~g}$ eq. catechin (CE) $\mathrm{kg}^{-1} \mathrm{dm}$ in Vicia faba cultivars. Variety with high tannin content (for example, var. Bobas) and variety with low tannin content (for example, var. Amulet) showed values of 7840 and $760 \mathrm{mg} \mathrm{CE} \mathrm{kg}^{-1} \mathrm{dm}$, respectively (Przywitowski et al. 2016). A $20 \%$ decrease of the condensed tannin content, just after MW treatment on processing day and regarding CTRL samples, was observed (Table 2). On the contrary, CP treatment did not affect the condensed tannin content (Table 2). Tannins can be considered as antinutritional factors, leading to reduced nutrient absorption, mineral availability, and protein digestibility (Díaz-Batalla et al. 2006), so the reduction of tannin content is an important point to be considered in a legumebased product. Similar results have been recently reported by Deng et al. (2015), which evaluated tannin content in buckwheat grains after MW treatment $(850 \mathrm{~W} ; 30 \mathrm{~min})$ reporting a decrease of $27.5 \%$ after the treatment. A possible explanation to this reduction could be related to the heat-labile nature of such compounds (Rakic et al. 2007). After 5 days at $5{ }^{\circ} \mathrm{C}$, the tannin content decreased in CTRL and CP samples without differences regarding MW samples. This trend was observed until the end of storage.

The total phenolic content of CTRL samples was higher $\left(2980 \pm 213 \mathrm{mg} \mathrm{GAE} \mathrm{kg}^{-1} \mathrm{fw}\right)$ than the one reported by Baginsky et al. (2013) in several varieties of faba bean immature seeds $(817.02 \pm 71.05$ to $1337.82 \pm 84.22 \mathrm{mg}$ GAE kg $\left.{ }^{-1} \mathrm{fw}\right)$. After thermal treatments, a reduction around 12 or $16 \%$ in CP and MW treatments, respectively, was observed (Table 2). In general, phenolic degradation may occur after thermal treatments and during storage due to enzymatic or chemical oxidation (Tomás-Barberán and Espín 2001). This trend was described by previous authors. Benlloch-Tinoco et al. (2015) detected that total phenolic content was reduced by 28.80 and $42.38 \%$ when kiwifruit puree was microwaved $(2 \mathrm{~W} / \mathrm{g}, 340 \mathrm{~s})$ and conventionally heat treated $\left(97^{\circ} \mathrm{C}, 30 \mathrm{~s}\right)$, respectively. In the same way, Picouet et al. (2009) founded that apple puree samples heated under MW conditions (652 W, $35 \mathrm{~s}$ ), achieving maximum product temperature of $75.3 \pm 4.8{ }^{\circ} \mathrm{C}$, showed 
Table 2 Total carotenoid and total chlorophyll content changes, total antioxidant capacity (FRAP and DPPH methods), total phenolic compounds (TPC), and condensed tannin changes during storage at $5{ }^{\circ} \mathrm{C}$ of untreated control (CTRL), conventional pasteurization (CP), and microwave (MW)treated faba bean pesto sauce

\begin{tabular}{|c|c|c|c|c|c|c|c|}
\hline Day & Treatment & $\begin{array}{l}\text { Total carotenoids } \\
\left(\mathrm{mg} \mathrm{kg}^{-1} \mathrm{fw}\right)\end{array}$ & $\begin{array}{l}\text { Total chlorophyll } \\
\left(\mathrm{mg} \mathrm{kg}^{-1} \mathrm{fw}\right)\end{array}$ & $\begin{array}{l}\text { FRAP } \\
\left(\mathrm{mg} \text { TEAC kg }{ }^{-1} \mathrm{fw}\right)\end{array}$ & 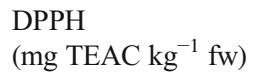 & $\begin{array}{l}\text { TPC (mg } \\
\text { GAE kg-1 fw) }\end{array}$ & $\begin{array}{l}\text { Condensed tannins } \\
\left(\mathrm{mg} \mathrm{CE} \mathrm{kg}^{-1} \mathrm{fw}\right)\end{array}$ \\
\hline \multirow[t]{3}{*}{0} & CTRL & $9.4 \pm 1.8 \mathrm{AB}$ & $31.6 \pm 5.7 \mathrm{~A}$ & $4146 \pm 109 \mathrm{Aa}$ & $1265 \pm 22 b$ & $2980 \pm 213 \mathrm{Aa}$ & $5942 \pm 390 \mathrm{Aa}$ \\
\hline & $\mathrm{CP}$ & $8.0 \pm 2.3 \mathrm{~B}$ & $29.5 \pm 3.4 \mathrm{~B}$ & $3672 \pm 119 \mathrm{ABa}$ & $1242 \pm 20 b$ & $2614 \pm 75 \mathrm{Ba}$ & $5838 \pm 64 \mathrm{Aa}$ \\
\hline & MW & $8.9 \pm 0.7 \mathrm{~A}$ & $31.5 \pm 4.0 \mathrm{~A}$ & $3564 \pm 210 \mathrm{Ba}$ & $1200 \pm 39 b$ & $2507 \pm 134 \mathrm{Ba}$ & $4730 \pm 210 \mathrm{Bns}$ \\
\hline \multirow[t]{3}{*}{5} & CTRL & $8.6 \pm 0.3 \mathrm{AB}$ & $32.5 \pm 0.9 \mathrm{~A}$ & $3548 \pm 13 \mathrm{Ab}$ & $1237 \pm 32 \mathrm{ab}$ & $2763 \pm 64 \mathrm{Aab}$ & $5048 \pm 26 \mathrm{NSab}$ \\
\hline & $\mathrm{CP}$ & $7.3 \pm 0.9 \mathrm{~B}$ & $24.3 \pm 5.2 \mathrm{~B}$ & $3178 \pm 207 \mathrm{ABb}$ & $1238 \pm 6 \mathrm{ab}$ & $2502 \pm 145 \mathrm{Bab}$ & $5331 \pm 525 \mathrm{NSab}$ \\
\hline & MW & $8.3 \pm 1.3 \mathrm{~A}$ & $30.0 \pm 1.2 \mathrm{~A}$ & $3275 \pm 58 \mathrm{Bb}$ & $1268 \pm 13 \mathrm{ab}$ & $2650 \pm 19 \mathrm{Bab}$ & $4770 \pm 400 \mathrm{NSns}$ \\
\hline \multirow[t]{3}{*}{8} & CTRL & $8.9 \pm 1.3 \mathrm{AB}$ & $30.8 \pm 0.1 \mathrm{~A}$ & $3509 \pm 59 \mathrm{Ab}$ & $1267 \pm 34 a b$ & $2584 \pm 95 \mathrm{Aab}$ & $5815 \pm 677 \mathrm{NSa}$ \\
\hline & $\mathrm{CP}$ & $7.2 \pm 0.4 \mathrm{~B}$ & $25.0 \pm 0.1 \mathrm{~B}$ & $3425 \pm 132 \mathrm{ABb}$ & $1271 \pm 27 \mathrm{ab}$ & $2598 \pm 170 \mathrm{Bab}$ & $4407 \pm 519 \mathrm{NSbc}$ \\
\hline & MW & $8.5 \pm 1.9 \mathrm{~A}$ & $29.1 \pm 0.2 \mathrm{~A}$ & $3373 \pm 178 \mathrm{Bb}$ & $1274 \pm 33 \mathrm{ab}$ & $2537 \pm 137 \mathrm{Bab}$ & $4973 \pm 1041 \mathrm{NSnns}$ \\
\hline \multirow[t]{3}{*}{14} & CTRL & $6.9 \pm 1.1 \mathrm{AB}$ & $29.4 \pm 5.6 \mathrm{~A}$ & $3512 \pm 155 \mathrm{Ab}$ & $1269 \pm 38 \mathrm{a}$ & $2588 \pm 175 \mathrm{Ab}$ & $4077 \pm 146 \mathrm{NSb}$ \\
\hline & $\mathrm{CP}$ & $6.9 \pm 0.2 \mathrm{~B}$ & $25.7 \pm 3.3 \mathrm{~B}$ & $3377 \pm 454 \mathrm{ABb}$ & $1250 \pm 4 \mathrm{a}$ & $2351 \pm 178 \mathrm{Bb}$ & $4050 \pm 14 \mathrm{NSc}$ \\
\hline & MW & $8.4 \pm 0.1 \mathrm{~A}$ & $28.2 \pm 6.0 \mathrm{~A}$ & $3130 \pm 134 \mathrm{Bb}$ & $1312 \pm 18 \mathrm{a}$ & $2359 \pm 171 \mathrm{Bb}$ & $4350 \pm 246 \mathrm{NSns}$ \\
\hline \multirow[t]{3}{*}{20} & CTRL & $7.3 \pm 0.3 \mathrm{AB}$ & $32.8 \pm 3.1 \mathrm{~A}$ & $3379 \pm 95 \mathrm{Aab}$ & $1266 \pm 23 \mathrm{ab}$ & $2500 \pm 239 \mathrm{Aab}$ & $4352 \pm 321 \mathrm{NSb}$ \\
\hline & $\mathrm{CP}$ & $7.0 \pm 0.9 \mathrm{~B}$ & $26.3 \pm 3.4 \mathrm{~B}$ & $3498 \pm 488 \mathrm{ABab}$ & $1247 \pm 15 \mathrm{ab}$ & $2501 \pm 291 \mathrm{Bab}$ & $4674 \pm 323 \mathrm{NSbc}$ \\
\hline & MW & $8.2 \pm 1.0 \mathrm{~A}$ & $35.8 \pm 3.0 \mathrm{~A}$ & $3500 \pm 692 \mathrm{Bab}$ & $1261 \pm 24 \mathrm{ab}$ & $2489 \pm 513 \mathrm{Bab}$ & $4074 \pm 98$ NSns \\
\hline \multicolumn{2}{|c|}{ Treatment } & $*$ & $* *$ & $*$ & NS & $*$ & $*$ \\
\hline \multicolumn{2}{|c|}{ Days } & NS & NS & $* *$ & $* *$ & $*$ & $* * *$ \\
\hline \multicolumn{2}{|c|}{ Days $\times$ treatment } & NS & NS & NS & $* *$ & NS & $* *$ \\
\hline
\end{tabular}

Values correspond to average value $(n=3) \pm \mathrm{SD}$. Different capital letters within the same column show significant differences between treatments. Different lowercase letters within the same column show significant differences between storage times

NS not significant

$* p<0.05 ; * * p<0.01 ; * * * p<0.001$

$26 \%$ loss of total phenolic content after 5 days of storage regarding the initial content. However, contradictory data to these results has also been reported. Zhou et al. (2016) observed that domestic MW oven treatments for 60 and $80 \mathrm{~s}$ at $11.0 \mathrm{~W} / \mathrm{g}$, reaching temperature of $100{ }^{\circ} \mathrm{C}$, increased total phenolic content by 12.8 and $29.0 \%$ in defatted avocado puree, respectively, regarding untreated samples. After 20 days at $5{ }^{\circ} \mathrm{C}$, MW-treated samples showed $0.7 \%$ losses of TPC regarding values on processing day, while CP- and CTRL-treated samples showed losses around 4.3 and $16 \%$, respectively (Table 2). During storage, total phenolic content was maintained, probably due to the PPO and POD enzyme inactivation, or because samples were kept in vacuum bags, and therefore PPO was not active to degrade the phenolic compounds. Benlloch-Tinoco et al. (2013) published that the inactivation of PPO and POD during microwave processing of kiwifruit puree was significantly faster in comparison with the conventional processes. Arjmandi et al. (2017) found microwave heating to be more effective at inactivating POD and preserving nutritional properties in tomato puree than conventional thermal treatment.
TEAC of the faba bean pesto sauce evaluated by FRAP and DPPH assays are presented in Table 2. In FRAP assay, TEAC showed a decrease around $14 \%$ in $\mathrm{MW}$ treatment regarding CTRL samples, although no differences between MW and CP samples were observed. After 5 days at $5{ }^{\circ} \mathrm{C}$, all samples reported a decrease of their antioxidant capacity, which was around $8 \%$ in MW-treated samples, while CP and CTRL samples showed losses around 14\% (Table 2). However, at the end of storage, no differences were observed regarding the initial day in CTRL, CP, and MW samples. On the other hand, the TEAC evaluated by DPPH assay, did not show differences among treatments, and it was well preserved during the 20 days of storage at $5{ }^{\circ} \mathrm{C}$ (Table 2). The different results observed between FRAP and DPPH assays were due to the different methodology based on both assays. DPPH tests the free radical scavenging activity, while FRAP evaluates the ferric reducing capacity of extracts (Brand-Williams et al. 1995; Benzie and Strain 1999).

The TPC and condensed tannins showed a high correlation in FRAP assay. The correlation coefficient between FRAP and TPC was positive and significant $(0.829$, $p<0.001)$, and that between FRAP and condensed tannins was positive and significant $(0.564, p<0.01)$. However, 


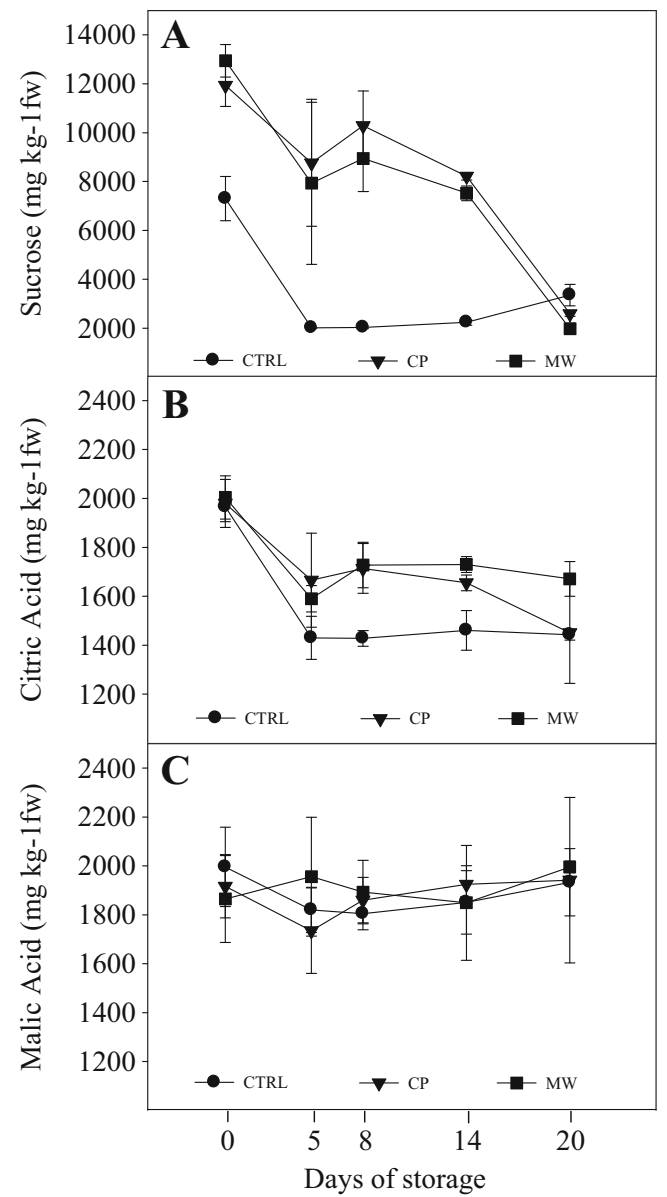

Fig. 2 Sucrose content (a) and organic acid content [citric (b) and malic (c)] changes during storage at $5{ }^{\circ} \mathrm{C}$ of untreated control (CTRL), conventional pasteurization (CP), and microwave (MW)-treated faba beans pesto sauce

no significant correlation was observed by DPPH assay. The correlation between FRAP assay and TPC corroborated with the results of Sinha et al. (2013) that reported a high positive relationship between total phenols and antioxidant capacity in faba bean seeds and that the antioxidant activity reported was largely because of its condensed tannins. We observed that the reduction of tannin content is in agreement with the reduction in the TEAC by FRAP assay. The antioxidant activity of flavonoids depends on the number of hydroxyl groups in their molecules, so a high concentration of procyanidins, rich in hydroxyl groups, increased the antioxidant capacity (Oszmianski et al. 2008).

\section{Effect of Thermal Treatments on Sensory Quality}

In sensory quality, no differences were observed among treatments on processing day. However, after 14 days at $5{ }^{\circ} \mathrm{C}$, thermally treated samples showed better taste than CTRL samples (Fig. 3a). In addition, CTRL samples were rejected by taste after 14 days at $5{ }^{\circ} \mathrm{C}$. A similar trend was observed in flavor, where MW samples and CP samples presented better flavor than CTRL samples (data not shown).

On the other hand, MW-treated samples showed the best color throughout storage, while CTRL samples showed the lowest score and CTRL samples were rejected by color after 20 days (Fig. 3b). Similar results were observed in texture, where MW and CP treatments provided the best texture to pesto sauce samples, while CTRL samples showed the worst (Fig. 3c). Furthermore, consistency was lower in CTRL samples than in thermally treated CP and MW samples (data not shown). As result, the shelf life of CTRL samples was lower than 14 days at $5{ }^{\circ} \mathrm{C}$; meanwhile, thermally treated samples presented a good acceptability up to 20 days at $5{ }^{\circ} \mathrm{C}$, mainly MW-treated samples (Fig. 3).

MW treatment provided a better ideal phase separation between oils and other components, like a typical pesto. In addition, a higher consistency of the product was observed during storage. In this way, among MW- and CPheated samples, MW samples were more consistent and had a better texture than CP or CTRL samples. In terms of sensory quality, the higher viscosity was better scored as it gives better mouthfeel. Zhou et al. (2016) studied the

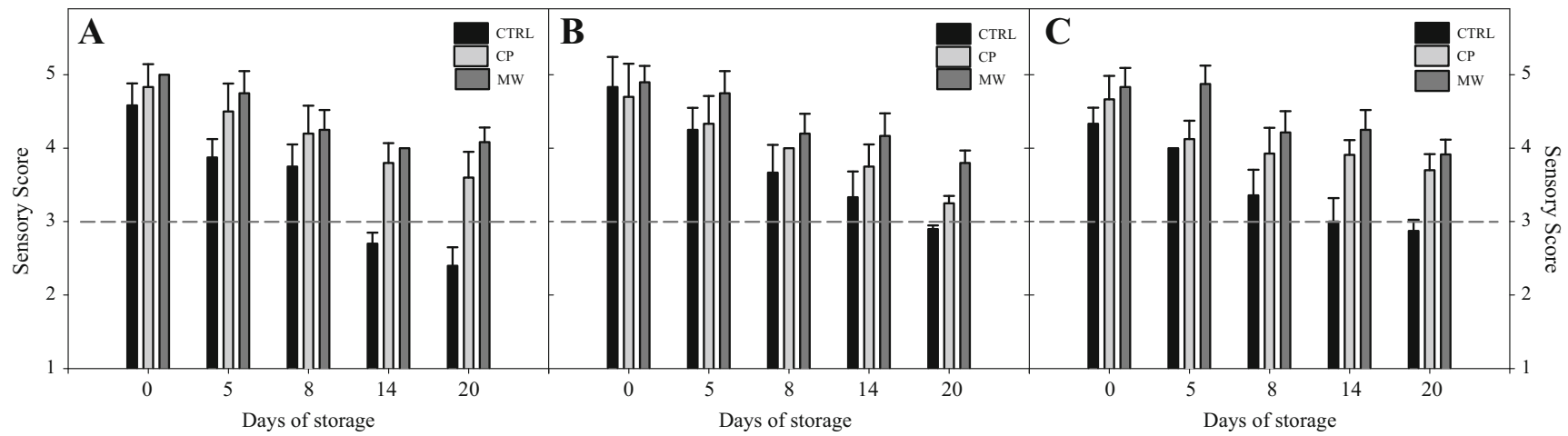

Fig. 3 Sensory quality [taste (a), color (b), and texture (c)] changes during storage at $5{ }^{\circ} \mathrm{C}$ of untreated control (CTRL), conventional pasteurization (CP), and microwave (MW)-treated faba beans pesto sauce 


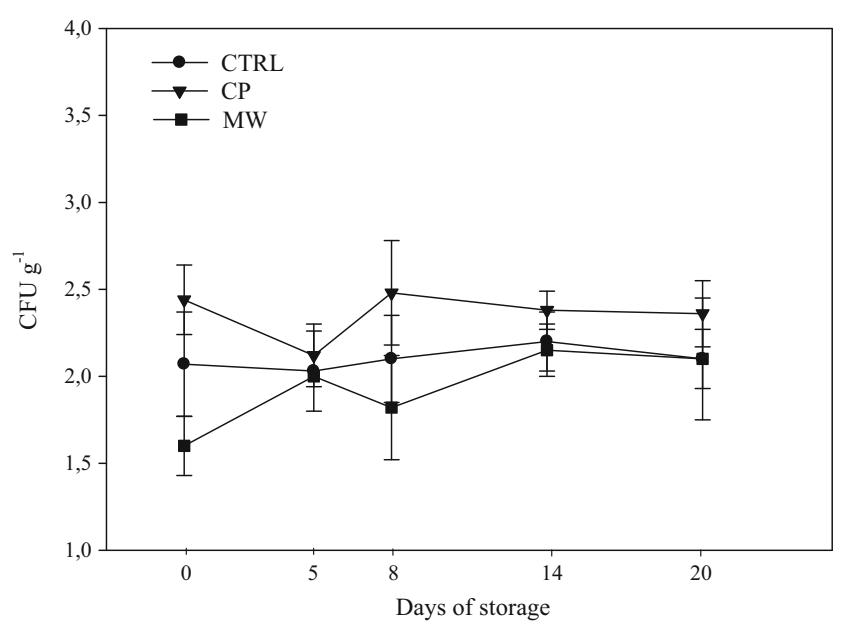

Fig. 4 Evaluation of mesophiles during storage at $5{ }^{\circ} \mathrm{C}$ of untreated control (CTRL), conventional pasteurization (CP), and microwave (MW)-treated faba beans pesto sauce

viscosity of defatted avocado puree treated by $\mathrm{MW}$ $(11.0 \mathrm{~W} / \mathrm{g}, 80 \mathrm{~s})$ and showed that the viscosity of this product increased after MW treatment. The increase in viscosity of microwaved-treated samples could be attributed to the rupture of the starch granules and reassociation of the amylopectin molecules which gradually gelatinized as a function of the vibrational motion of the polar molecules during the microwave treatment (BilbaoSáinz et al. 2007).

The taste showed a high correlation with condensed tannins, citric acid, and sucrose. The correlation coefficients between taste and condensed tannins were positive and significant $(0.464, p<0.01)$, those between taste and citric acid were positive and significant $(0.578, p<0.001)$, and those between taste and sucrose were positive and significant $(0.681$, $p<0.001$ ).

Concerning sensory taste, we observed a better acceptability of thermally treated faba bean pesto sauce samples, mainly in MW samples. A possible reason could be the highest sucrose content and the lowest astringent taste, which could be related to the lowest condensed tannin content regarding CTRL samples. Troszynska et al. (2006) evaluated astringency and protein precipitation activity from faba bean and broad bean extracts and was reported that phenolic extracts from these legume seeds have acted as effective astringents. Also, Troszynska et al. (2006) observed that the extracts showed precipitation ability of the heterogeneous proteins which naturally existed in human salivary (HSPs) and in bovine serum albumin (BSA) protein, which indicates that their astringency was responsible for condensed tannins. Additionally, tannin content might also reduce food acceptance due to change in sensory quality as a result of alter astringency, bitterness, and texture of food products.

\section{Effect of Thermal Treatments on Microbial Analyses}

All samples showed low aerobic mesophilic counts $(<3 \log$ $\mathrm{CFU} \mathrm{g}^{-1}$ ) during storage, without differences between treatments and storage time (Fig. 4). Psychrotrophic bacteria, enterobacteria, and mold and yeast counts were maintained below the detection limit $\left(<1 \log \mathrm{CFU} \mathrm{g}^{-1}\right.$ for bacteria and $<2 \log \mathrm{CFU} \mathrm{g}^{-1}$ for molds and yeasts) (data not shown). No Salmonella spp., Listeria monocytogenes, and generic Escherichia coli presence was detected throughout storage according to Regulation EC 1441/2007 (2007). According to our results, Marszalek et al. (2016) evaluated the microbial stability (total microbial count and molds and yeasts) of strawberry puree preserved with continuous MW processing and $\mathrm{CP}$, both treatments reaching the temperature of $90 \pm 1{ }^{\circ} \mathrm{C}$, and the microbial counts remained in $2-3$ and $<1 \log \mathrm{CFU} \mathrm{g}{ }^{-1} \mathrm{fw}$ for mold and yeast counts, respectively, until the end of the storage.

In agreement with the low counts detected for all analyzed microorganisms, no $\mathrm{pH}$ alteration was detected. In fact, the microbial load does not reduce the shelf life of faba bean pesto sauce, due to the efficacy of the thermal treatment, among other factors like good manufacture practices and storage conditions. The vacuum packaging of the samples could also contribute to the maintenance of the initial low counts of microorganisms during storage, and additionally, those microorganisms that were damaged after the thermal treatment could not be recovered during the storage.

\section{Conclusions}

The alternative mild pasteurization applied by different technologies showed differences in sensory quality of the faba bean pesto sauce. Physicochemical properties, especially color, were greatly influenced by heat treatments, wherein MW treatment was able to preserve greenness, and improve the consistency, texture, and taste. In addition, degradation of condensed tannins by MW is an interesting alternative to conventional pasteurization for astringent cooked food. Therefore, MW is an efficient technology to apply in faba bean pesto sauce to improve its physicochemical, nutritional, and sensorial quality regarding conventional pasteurization and maintaining the quality of the pesto sauce throughout 20 days at $5{ }^{\circ} \mathrm{C}$.

Acknowledgments The authors are grateful to European Project EUROLEGUME (Seventh Research Framework Programme of the European Union-FP7 research project no. 613781). The authors express their gratitude to $\mathrm{CNPq}$ (Council for Scientific and Technological Development, Brazil) for a doctoral grant (232758/2014-0) to Tâmmila Venzke Klug. A. Martínez-Sánchez is the holder of a postdoctoral grant ('Juan de la Cierva') from the Spanish Government (MINECO). We are also grateful to Daniel Tock for his technical assistance. 
Open Access This article is distributed under the terms of the Creative Commons Attribution 4.0 International License (http:// creativecommons.org/licenses/by/4.0/), which permits unrestricted use, distribution, and reproduction in any medium, provided you give appropriate credit to the original author(s) and the source, provide a link to the Creative Commons license, and indicate if changes were made.

\section{References}

ASTM. (1986). Physical requirements guidelines for sensory evaluation laboratories (Vol. 913, ASTM Special Technical Pub. 913). Philadelphia: American Society for Testing Materials.

Almeida, D. T., Greiner, R., Furtunado, D. M. N., Trigueiro, I. N. S., \& Araújo, M. P. N. (2008). Content of some antinutritional factors in bean cultivars frequently consumed in Brazil. International Journal of Food Science \& Technology, 43(2), 243-249. https://doi.org/10. $1111 / j .1365-2621.2006 .01426 . x$.

Arjmandi, M., Otón, M., Artés, F., Artés-Hernández, F., Gómez, P. A., \& Aguayo, E. (2017). Microwave flow and conventional heating effects on the physicochemical properties, bioactive compounds and enzymatic activity of tomato puree. Journal of the Science of Food and Agriculture, 97(3), 984-990. https://doi.org/10.1002/jsfa.7824.

Arjmandi, M., Otón, M., Artés, F., Artés-Hernández, F., Gómez, P. A., \& Aguayo, E. (2016). Continuous microwave pasteurization of a vegetable smoothie improves its physical quality and hinders detrimental enzyme activity. Food Science and Technology International, 23(1), 36-45. https://doi.org/10.1177/1082013216654414.

Baginsky, C., Peña-Neira, A., Cáceres, A., Hernández, T., Estrella, I., Morales, H., \& Pertuzé, R. (2013). Phenolic compound composition in immature seeds of faba bean (Vicia faba L.) varieties cultivated in Chile. Journal of Food Composition and Analysis, 31(1), 1-6. https://doi.org/10.1016/j.jfca.2013.02.003.

Benlloch-Tinoco, M., Igual, M., Rodrigo, D., \& Martínez-Navarrete, N. (2013). Comparison of microwaves and conventional thermal treatment on enzymes activity and antioxidant capacity of kiwifruit puree. Innovative Food Science \& Emerging Technologies, 19, 166172. https://doi.org/10.1016/j.ifset.2013.05.007.

Benlloch-Tinoco, M., Igual, M., Salvador, A., Rodrigo, D., \& MartínezNavarrete, N. (2014). Quality and acceptability of microwave and conventionally pasteurized kiwifruit puree. Food and Bioprocess Technology, 7(11), 3282-3292. https://doi.org/10.1007/s11947014-1315-9.

Benlloch-Tinoco, M., Igual, M., Rodrigo, D., \& Martínez-Navarrete, N. (2015). Superiority of microwaves over conventional heating to preserve shelf-life and quality of kiwifruit puree. Food Control, 50, 620-629. https://doi.org/10.1016/j.foodcont.2014.10.006.

Benzie, I. F., \& Strain, J. J. (1999). Ferric reducing/antioxidant power assay: direct measure of total antioxidant activity of biological fluids and modified version for simultaneous measurement of total antioxidant power and ascorbic acid concentration. Methods in Enzymology, 299, 15-27. https://doi.org/10.1016/S0076-6879(99) 99005-5.

Bilbao-Sáinz, C., Butler, M., Weaver, T., \& Bent, J. (2007). Wheat starch gelatinization under microwave irradiation and conduction heating. Carbohydrate Polymers, 69(2), 224-232. https://doi.org/10.1016/j. carbpol.2006.09.026.

Bornhorst, E. R., Liu, F., Tang, J., Sablani, S. S., \& Barbosa-Cánovas, G. V. (2017). Food quality evaluation using model foods: a comparison study between microwave-assisted and conventional thermal pasteurization process. Food and Bioprocess Technology, 10(3), 1248-1256. https://doi.org/10.1007/s11947-017-1900-9.

Brand-Williams, W., Cuvelier, M. E., \& Berset, C. (1995). Use of free radical method to evaluate antioxidant activity. LWT-Food Science and Technology, 28(1), 25-30. https://doi.org/10.1016/S00236438(95)80008-5.

Cano, M. P. (1991). HPLC separation of chlorophyll and carotenoid pigments of four kiwi fruit cultivars. Journal of Agricultural and Food Chemistry, 39(10), 1786-1791. https://doi.org/10.1021/ jf00010a019.

Castillejo, N., Martínez-Hernández, G. B., Gómez, P. A., Artés, F., \& Artés-Hérnandez, F. (2016). Red fresh vegetables smoothies with extended shelf life as an innovative source of health-promoting compounds. Journal of Food Science and Technology, 53(3), 14751486. https://doi.org/10.1007/s13197-015-2143-2.

Castillejo, N., Martínez-Hernández, G. B., Lozano-Guerrero, A. J., Pedreño-Molina, J. L, Gómez, P. A., Aguayo, E., Artés, F., \& Artés-Hérnandez F. (2017). Microwave heating modelling of a green smoothie. Effects on glucoraphanin, sulforaphane and $s$ -methylcysteine sulphoxide changes during storage. Journal of the Science of Food and Agriculture. In press. doi: https://doi.org/10. $1002 /$ jsfa. 8665.

De Ancos, B., Cano, M. P., Hernández, A., \& Monreal, M. (1999). Effects of microwave heating on pigment composition and colour of fruit purées. Journal of the Science of Food and Agriculture, 79(5), 663670. https://doi.org/10.1002/(SICI)1097-0010(199904)79:5<663:: AID-JSFA232>3.0.CO;2-L.

Deng, Y., Padilla-Zakour, O., Zhao, Y., \& Tao, S. (2015). Influences of high hydrostatic pressure, microwave heating, and boiling on chemical compositions, antinutritional factors, fatty acids, in vitro protein digestibility, and microstructure of buckwheat. Food and Bioprocess Technology, 8(11), 2235-2245. https://doi.org/10.1007/s11947-0151578-9.

Díaz-Batalla, L., Widholm, J. M., Fahey, G. C., Castano-Tostado, E., \& Paredes-Lopez, O. (2006). Chemical components with health implications in wild and cultivated Mexican common bean seeds (Phaseolus vulgaris L.) Journal of Agricultural and Food Chemistry, 54(6), 2045-2052. https://doi.org/10.1021/jf0517061.

Flores, P., Hellín, P., \& Fenoll, J. (2012). Determination of organic acids in fruits and vegetables by liquid chromatography with tandem-mass spectrometry. Food Chemistry, 132(2), 1049-1054. https://doi.org/ 10.1016/j.foodchem.2011.10.064

Guzmán, G. R., Dorantes, A. L., Hernández, U. H., Hernández, S. H., Ortíz, A., \& Mora, E. R. (2002). Effect of zinc and copper chloride on the color of avocado puree heated with microwaves. Innovative Food Science \& Emerging Technologies, 3(1), 47-53. https://doi. org/10.1016/S1466-8564(01)00053-4.

Hedley, C. (2001). Carbohydrates in grain legume seeds. Improving nutritional quality and agronomic characteristics. Wallingford: CABI Publishing.

Hefni, M. E., Shalaby, M. T., \& Witthöft, C. M. (2015). Folate content in faba beans (Vicia faba L.) - effects of cultivar, maturity stage, industrial processing, and bioprocessing. Food Science \& Nutrition, 3(1), 65-73. https://doi.org/10.1002/fsn3.192.

ISO (2007). Sensory analysis-general guidance for the design of test rooms. In ISO (Ed.), (Vol. 8589:2007). ISO.

Klug, T. V., Martínez-Sánchez, A., Gómez, P., Collado, E., Aguayo, E., Artés, F., \& Artés-Hernández, F. (2017). Improving quality of a pea puree by high hydrostatic pressure. Journal of the Science of Food and Agriculture, 97(13), 4362-4369. https://doi.org/10.1002/jsfa. 8454.

Lima, A. I. G., Mota, J., Monteiro, S. A. V. S., \& Ferreira, R. M. S. B. (2016). Legume seeds and colorectal cancer revisited: protease inhibitors reduce MMP-9 activity and colon cancer cell migration. Food Chemistry, 197(Pt A), 30-38. https://doi.org/10.1016/j. foodchem.2015.10.063.

Lisiewska, Z., Kmiecik, W., \& Słupski, J. (2004). Contents of chlorophylls and carotenoids in frozen dill: effect of usable part and pretreatment on the content of chlorophylls and carotenoids in frozen dill (Anethum graveolens L.), depending on the time and 
temperature of storage. Food Chemistry, 84(4), 511-518. https://doi. org/10.1016/S0308-8146(03)00265-6.

Marszalek, K., Mitek, M., \& Skapska, S. (2015). Effect of continuous flow microwave and conventional heating on the bioactive compounds, color, enzyme activity, microbial and sensory quality of strawberry puree. Food and Bioprocess Technology, 8(9), 1864 1876. https://doi.org/10.1007/s11947-015-1543-7.

Marszalek, K., Woźniak, L., Skapska, S., \& Mitek, M. (2016). A comparative study of the quality of strawberry purée preserved by continuous microwave heating and conventional thermal pasteurization during long-term cold storage. Food and Bioprocess Technology, 9(7), 1100-1112. https://doi.org/10.1007/s11947-016-1698-x.

Martínez-Hernández, G. B., Gómez, P. A., Pradas, I., Artés, F., \& ArtésHernández, F. (2011). Moderate UV-C pretreatment as a quality enhancement tool in fresh-cut Bimi ${ }^{\circledR}$ broccoli. Postharvest Biology and Technology, 62(3), 327-337. https://doi.org/10.1016/j. postharvbio.2011.06.015.

Murcia, M. A., López, A. B., Martínez, T. M., \& García, C. F. (2000). Effect of industrial processing on chlorophyll content of broccoli. Journal of the Science of Food and Agriculture, 80(10), 1447-1451. https://doi.org/10.1002/1097-0010(200008)80:10<1447::AIDJSFA670>3.0.CO;2-X.

Oszmianski, J., Wolniak, M., Wojdyło, A., \& Wawer, I. (2008). Influence of apple purée preparation and storage on polyphenol contents and antioxidant activity. Food Chemistry, 107(4), 1473-1484. https:// doi.org/10.1016/j.foodchem.2007.10.003.

Petzold, G., Caro, M., \& Moreno, J. (2014). Influence of blanching, freezing and frozen storage on physicochemical properties of broad beans (Vicia faba L). International Journal of Refrigeration, 40, 429-434. https://doi.org/10.1016/j.ijrefrig.2013.05.007.

Picouet, P. A., Landl, A., Abadías, M., Castellari, M., \& Viñas, I. (2009). Minimal processing of a Granny Smith apple purée by microwave heating. Innovative Food Science \& Emerging Technologies, 10(4), 545-550. https://doi.org/10.1016/j.ifset.2009.05.007.

Price, M. L., Scoyoc, S. V., \& Butler, L. (1978). A critical evaluation of the vanillin reaction as an assay for tannin on sorghum grain. Journal of Agricultural and Food Chemistry, 26(5), 1214-1218. https://doi.org/10.1021/jf60219a031.

Przywitowski, M., Mikulski, D., Zdunczyk, Z., Rogiewicz, A., \& Jankowski, J. (2016). The effect of dietary high-tannin and lowtannin faba bean (Vicia faba L.) on the growth performance, carcass traits and breast meat characteristics of finisher turkeys. Animal Feed Science and Technology, 221, 124-136. https://doi.org/10. 1016/j.anifeedsci.2016.08.027.

Rakic, S., Petrovic, S., Kukic, J., Jadranin, M., Tesevic, V., \& Povrenovic, D. (2007). Influence of thermal treatment on phenolic compounds and antioxidant properties of oak acorns from Serbia. Food Chemistry, 104(2), 830-834. https://doi.org/10.1016/j.foodchem. 2007.01.025.

Randhir, R., \& Shetty, K. (2004). Microwave-induced stimulation of lLDOPA, phenolics and antioxidant activity in faba bean (Vicia faba) for Parkinson's diet. Process Biochemistry, 39(11), 1775-1784. https://doi.org/10.1016/j.procbio.2003.08.006.

Rao, P. U., \& Belavady, B. (1978). Oligosaccharides in pulses: varietal differences and effects of cooking and germination. Journal of Agricultural and Food Chemistry, 26(2), 316-319. https://doi.org/ $10.1021 / \mathrm{jf} 60216 \mathrm{a} 044$.

Regulation EC 1441/2007. (2007). Commission regulation on microbiological criteria for foodstuffs. Official Journal of the European Union, 322, 12-29.
Rodríguez-Hidalgo, S., Artés-Hernández, F., Gómez, P. A., Fernández, J. A., \& Artés, F. (2010). Quality of fresh-cut baby spinach grown under a floating trays system as affected by nitrogen fertilisation and innovative packaging treatments. Journal of the Science of Food and Agriculture, 90(6), 1089-1097. https://doi.org/10.1002/ jsfa.3926.

Shimelis, E., \& Rakshit, S. (2005). Effect of microwave heating on solubility and digestibility of proteins and reduction of antinutrients of selected common bean (Phaseolus Vulgaris L.) varieties grown in Ethiopia. Italian Journal of Food Science, 17(4), 407-418.

Singleton, V. L., \& Rossi, J. A. (1965). Colorimetry of total phenolics with phospomolobdic-phosphotungstic acid reagents. American Journal of Enology and Viticulture, 16, 144-158.

Sinha, S. K., Kumar, M., Kumar, A., Bharti, S., \& Shahi, V. K. (2013). Antioxidant activities of different tissue extract of faba bean (Vicia faba L.) containing phenolic compounds. Legume Research, 36(6), 496-504.

Tomás-Barberán, F. A., \& Espín, J. C. (2001). Phenolic compounds and related enzymes as determinants of quality in fruits and vegetables. Journal of the Science of Food and Agriculture, 81(9), 853-876. https://doi.org/10.1002/jsfa.885.

Troszynska, A., Amarowicz, R., Lamparski, G., Wołejszo, A., \& Baryłko-Pikielna, N. (2006). Investigation of astringency of extracts obtained from selected tannins-rich legume seeds. Food Quality and Preference, 17(1), 31-35. https://doi.org/10.1016/j.foodqual.2005. 04.006 .

Van het Hof, K. H., de Boer, B. C., Tijburg, L. B., Lucius, B. R., Zijp, I., West, C. E., Hautvast, J. G., \& Weststrate, J. A. (2000). Carotenoid bioavailability in humans from tomatoes processed in different ways determined from the carotenoid response in the triglyceride-rich lipoprotein fraction of plasma after a single consumption and in plasma after four days of consumption. Journal of Nutrition, 130(5), 1189-1196.

Vidal-Valverde, C., Frias, J., Sotomayor, C., Díaz-Pollan, C., Fernández, M., \& Urbano, G. (1998). Nutrients and antinutritional factors in faba beans as affected by processing. European Food Research and Technology, 207(2), 140-145.

Walkling-Ribeiro, M., Noci, F., Cronin, D. A., Lyng, J. G., \& Morgan, D. J. (2010). Shelf life and sensory attributes of a fruit smoothie-type beverage processed with moderate heat and pulsed electric fields. LWT - Food Science and Technology, 43(7), 1067-1073. https://doi. org/10.1016/j.lwt.2010.02.010.

Wellburn, A. R. (1994). The spectral determination of chlorophylls a and $\mathrm{b}$, as well as total carotenoids, using various solvents with spectrophotometers of different resolution. Journal of Plant Physiology, 144(3), 307-313. https://doi.org/10.1016/S0176-1617(11)81192-2.

Zhao, L., Wang, S. Y., Liu, F. X., Dong, P., Huang, W. S., Xiong, L., \& Liao, X. J. (2013). Comparing the effects of high hydrostatic pressure and thermal pasteurization combined with nisin on the quality of cucumber juice drinks. Innovative Food Science \& Emerging Technologies, 17, 27-36. https://doi.org/10.1016/j.ifset.2012.10. 004.

Zhou, L., Tey, C. Y., Bingol, G., \& Bi, J. (2016). Effect of microwave treatment on enzyme inactivation and quality change of defatted avocado puree during storage. Innovative Food Science \& Emerging Technologies, 37, 61-67. https://doi.org/10.1016/j.ifset. 2016.08.002. 